\title{
Presentación
}

\author{
Graciela SALTO (coordinadora) \\ Universidad Nacional de La Pampa-CONICET \\ salto.graciela@gmail.com
}

\section{Formación e invención de tradiciones literarias: perspectivas recientes}

Una escena de remembranzas clásicas organiza la trama de "Que trine Eva", un relato de Reinaldo Arenas, fechado en 1971: Eva teje y no deja de tejer. Lo hace para vestir un cuerpo que solo existe en la experiencia de la escritura y, al hacerlo, comienza a desatar los nudos del relato nacional. Es una metáfora potente sobre el intenso proceso de rearticulación de las tradiciones literarias producido en las últimas décadas del siglo veinte e inicios del presente. No es un proceso nuevo, pero sí muy significativo para analizar la literatura latinoamericana de hoy, ya que permite atisbar los nexos interdiscursivos e intertextuales que han incidido en la transformación de un corpus que siempre teje y desteje un imaginario compartido.

Los primeros esfuerzos por vincular las incipientes literaturas del continente datan de mediados del siglo XIX. En ese período se bosquejaron muchas de las tramas, figuras, linajes y genealogías que definirían lo latinoamericano en las décadas posteriores (Díaz Quiñones). Se formaron como respuestas a las pulsiones de la modernización y se afianzaron en el entrecruzamiento diacrónico de las variables históricas con algunas de las estrategias literarias de mayor innovación estética. Susana Zanetti (1994) destacó hace varios años la encrucijada religadora del modernismo finisecular y otros críticos insistieron, además, en los vínculos literarios y artísticos de los distintos movimientos de vanguardias y en la ampliación y legitimación de una mirada continental también durante la década de 1960.

Estos trayectos de lecturas y su incidencia en el diseño y la articulación de tradiciones literarias han sido puestos en entredicho en las últimas décadas, en congruencia con las transformaciones espectaculares de los medios de producción y de recepción y el avance de las industrias de la información sobre las prácticas artísticas y editoriales. Sin embargo, en un contexto en apariencia muy diferente, la pregunta por la literatura latinoamericana mantiene todavía su potencial crítico. Sigue existiendo un repertorio a partir del cual se reordenan 
lecturas del pasado en nuevas series significativas y se ponderan estrategias, procedimientos, líneas y tópicos que alcanzan nueva capacidad operativa.

El narrador colombiano, Pablo Montoya, declara en una entrevista reciente: "Se creía que los modernistas desdeñaban los contornos de la identidad americana. Pero, en realidad, no la menospreciaron sino que la estaban ampliando de modo inquietante" (Foffani). No es una declaración que pueda soslayarse en un autor que se confiesa heredero de esa voracidad modernista por el conocimiento de lo más exótico y diverso y que opera, en sus novelas, con un repertorio de textos, imágenes y músicas de tan variada procedencia. El estudio de Mónica Marinone que abre este dossier se centra, precisamente, en los efectos disruptivos de los materiales excéntricos que nutren la narrativa de Montoya y en su peculiar rediseño del imaginario latinoamericanista a partir de lecturas y apropiaciones estéticas poco frecuentes. Así como los modernistas ampliaron "de modo inquietante" el horizonte de referencias, también Montoya parece avanzar, en los últimos años, en la organización de un archivo inesperado que ofrece nuevos modos de narrar y de leer lo latinoamericano.

Estos cambios de percepción sobre las configuraciones simbólicas del pasado también llegaron hasta el ámbito de la lexicografía. El autor cubano estadounidense, Gustavo Pérez Firmat, ha postulado, en varios ensayos sobre la experiencia del desarraigo, la relevancia actual de un antiguo repertorio léxico: Un catauro de cubanismos, publicado por Fernando Ortiz en 1923. Ese registro de etimologías africanistas, escrito en un tono irreverente y desenfadado, ofrece un repertorio de voces que, desde el pasado, convoca a los migrantes que hoy bucean ante el extrañamiento de una lengua que ha dejado de ser la propia. "No se repite lo pasado, - dice Werner Hamacher - sino lo que de él va al futuro. La filología repite este proceso y busca del futuro lo que le falta del pasado" (29). En ese punto de inflexión, el antiguo diccionario de inicios del siglo XX se actualiza desde la diáspora y sus etimologías pueden ser leídas con el mismo potencial disruptivo que los juegos verbales del Ulysses de James Joyce o The Waste Land de T. E. Eliot.

La investigación de María Fernando Pampín sobre los vínculos entre la obra de José Martí y algunos de los núcleos más productivos del pensamiento estadounidense de la época ofrece, también, un modo de interlocución con otras lecturas modernistas que complejizan los debates del presente. A contrapelo de una vasta bibliografía que tiende a encerrar la obra martiana en el cerco hermenéutico de la literatura cubana y latinoamericana, Pampín explora el entrelugar del escritor exiliado en New York y sus modos de interacción con las ideas que impregnaban un período de cambios y aceleración constante. En las citas, los comentarios o las traducciones martianas de los textos de Ralph 
Emerson y Walt Whitman, la autora describe estrategias de apropiación de ese frenesí moderno y analiza el modo en que esa tradición foránea ofreció matrices conceptuales que permitieron ampliar y reelaborar el archivo latinoamericanista.

Ese archivo reconoce entre sus hitos fundacionales una colección poética que data de 1833: las Rimas americanas del cubano Domingo del Monte. En esa antología precursora se exhiben las tensiones todavía irresueltas en torno a los elementos que habrían de conformar la americanidad a la vez que se ofrece un ejemplo temprano del proceso que se ha llamado "invención de tradiciones" (Hobsbawn) o "formación de tradiciones" (Burke, Kabatek). María Pía Bruno dedica su estudio al análisis de este episodio fundacional de la literatura hispanoamericana y a la descripción de sus complejas articulaciones con la situación política y económica de la época.

Lucía Stecher y Natalia Cisterna se centran en la formación de una tradición narrativa escrita por mujeres. Su investigación contrasta las escenas de amistad femenina en los relatos Luz y sombra (1903) de la puertorriqueña Ana Roqué y en Las memorias de Mamá Blanca (1929) de la venezolana Teresa de la Parra. Allí analizan la construcción de espacios de interacción literaria donde las protagonistas tienen la posibilidad de distanciarse de los mandatos y modelos de femineidad que imponía la sociedad patriarcal y generar otros lazos intersubjetivos. La lectura en voz alta, la escritura e intercambio de cartas, el compartir manuscritos que narran la propia historia, se convierten en actividades fundamentales para la formación de estos vínculos entre mujeres y estos prefiguran, a su vez, algunos rasgos del mentado giro autobiográfico de las últimas décadas.

La productividad de actualizar un repertorio cultural en un contexto distinto de aquel en el cual fue producido se ejemplifica con la lectura afiliativa del célebre Sueño de Sor Juana Inés de la Cruz en la obra de José Lezama Lima. En el ensayo de 1957, La expresión americana, Lezama lee un conjunto de procedimientos característicos del Barroco como posibilidad de encarnar la rebeldía criolla y de reclamar con voz propia la confluencia de la cultura europea y la americana. En este cruce epistémico, Olga Santiago analiza las estrategias retóricas y conceptuales que incorporan el poema de la escritora mejicana en una constelación de discursos orientada a demostrar la existencia de una tradición literaria criolla en medio de las tensiones sobre el universalismo que signaron la segunda posguerra.

Idalia Morejón Arnaiz, a su vez, se centra en el cuento "Que trine Eva" (1971) de Reinaldo Arenas, incorporado en el volumen póstumo Viaje a La Habana (1990). La metáfora del tejido femenino ante el esposo ausente es un 
relato crítico de emancipación ideológica y sexual. Ante un Estado que regula los cuerpos, el consumo e, incluso, los modos del vestuario, el tejido y la moda abren un espacio de visibilidad y reapropiación de lo silenciado y obturado. El cuerpo del relato es obediente a su deseo y resiste la imposición disciplinaria de los parámetros de vestimenta revolucionarios. La antigua imagen de la mujer tejedora y costurera adquiere así un poder revulsivo y paródico que pone en cuestionamiento la linealidad de esa tradición y exhibe, en cambio, varias estrategias de transformación de sus elementos constitutivos.

Si toda lectura del pasado es también una experiencia del presente a la vez que una expectativa sobre el futuro (Koselleck), es en este cruce de coordenadas donde se sitúan los artículos reunidos en este dossier. Entre todos, esbozan un estado de la cuestión sobre los procesos de invención, formación y transformación de tradiciones literarias y discursivas y proyectan, a su vez, nuevos itinerarios de lecturas sobre el imaginario cultural latinoamericano.

\section{BIBLIOGRAFÍA}

BURKE, Peter.

2004 ¿Qué es la historia cultural? Barcelona: Paidós, 2006.

DÍAZ QUIÑONES, Arcadio.

2006 Sobre los principios. Los intelectuales caribeños y la tradición. Bernal: Universidad Nacional de Quilmes.

FOFFANI, Enrique.

2015 "Descubriendo América. Entrevista a Pablo Montoya", Página/12, Suplemento Radar 12, 6 de diciembre de 2015. En línea. Consultado el 3 de marzo de 2016.

HAMACHER, Werner.

201195 tesis sobre la Filología. Buenos Aires: Miño y Dávila.

HoBSBAWM, Eric.

1983 "Inventando tradiciones", Historias, n 19, octubre 1987-marzo 1988, pp. 3-15.

KABATEK, Johannes.

2005 "À propos de l'historicité des textes", en Adolfo Murguía (ed.). Sense et références. Mélanges Georges Kleiber. Tübingen: Narr, pp. 149-156.

KOSELLECK, Reinhart. 
1993 “'Espacio de experiencia' y 'Horizonte de expectativa', dos categorías históricas", en Futuro pasado. Para una semántica de los tiempos históricos. Barcelona: Paidós, pp. 333-357.

ZANETTI, Susana.

1994 "Modernidad y religación: una perspectiva continental (18801916)", en América Latina: Palabra, Literatura e Cultura. Ana Pizarro, org. Sâo Paulo: UNICAMP, vol. II, pp. 489-534. 